\title{
Influence of acidogenic fermented fish by-products with rice bran for sludge reduction and biogas recovery in anaerobic co-digestion
}

\author{
Hee-Jeong Choi ${ }^{\dagger}$ \\ Department of Biosystems and Convergence Engineering, Catholic Kwandong University, 579-24, Beomil-ro, Gangneung-Si, Gangwon-do, 25601, Republic of Korea
}

\begin{abstract}
The purpose of this study was to investigate the effects of acidogenic fermentation broth with rice bran (RFFB), tap water (TFFB), or raw fishery by-products (FBs) on sludge reduction and biogas production in an anaerobic co-digestion process. Acidogenic fermentation of FBs with rice bran was faster and produced more volatile fatty acids than that with tap water. Reduction efficiencies for chemical oxygen demand, volatile solids, and total solids were highest in RFFB. In the kinetic analysis, $\lambda(\mathrm{d})$, which represents the duration of the lag phase, was shortest with RFFB $(1.09 \mathrm{~d})$ and highest in sewage sludge $(8.86 \mathrm{~d})$. As the loading amount of volatile solids and chemical oxygen demand increased, the amount of cumulative biogas also increased. Amount of produced methane and energy recovery were highest with RFFB (5.71 kWh). Anaerobic co-digestion of FFB and sewage sludge allowed reduced sludge and recovered energy using the discarded waste as an organic carbon source.
\end{abstract}

Keywords: Anaerobic fermentation acid broth, Anaerobic co-digestion, Biogas, Fishery by-product, Rice bran, Sludge reduction

\section{Introduction}

Sewage sludge production in Korea is continuously increasing by $5.9 \%$ per year, and an estimated $27,080\left(\mathrm{~m}^{3} / \mathrm{d}\right)$ of sewage sludge will be generated in 2020 [1]. The cost of sewage sludge treatment has also increased. The cost of treatment in 2006 was approximately 87.7 billion KRW and is predicted to be more than 191.4 billion KRW in 2020 [2]. Currently, most of the sewage sludge in Korea is landfilled (17.9\%), incinerated (30.6\%), or recycled (51.6\%), requiring large area and high energy costs for incineration and landfilling [1, 2]. Accordingly, the sewage sludge treatment problem has become a very important issue for maintaining a healthy environment as well as reducing costs [3]. Therefore, researchers are applying various methods such as thermal hydrolysis, hydrodynamics, and solubilization technology (by ultrasonic and mesophilic digestion) to reduce sewage sludge [3, 4]. However, these methods require high power consumption, high installation/operating costs, and additional chemicals [3]. Therefore, many companies have recently attempted anaerobic co-digestion that can reduce sewage sludge at low cost and produce biogas as a byproduct.
Anaerobic co-digestion is a process in which organic waste is mixed with sewage sludge in an anaerobic tank to decompose biologically degradable organic matter into methane and carbon dioxide in the absence of molecular oxygen [5]. This anaerobic co-digestion process can increase sludge digestion efficiency of the anaerobic digester to reduce sewage sludge, resulting in reduced sludge treatment cost, and the produced biogas can be used as an alternative energy source [3, 6]. In addition, anaerobic co-digestion can reduce construction cost when using existing digesters, and the digestion efficiency of the digester can be increased by injecting organic materials into a sewage treatment plant operated at low load [7]. Moreover, the organic acid produced in the acidogenic fermentation process can be used as an external carbon source for denitrification treatment [8]. Thus, organic wastes, various materials such as food waste, livestock manure, and biomass are used in the process [9-13]. However, studies on reduction of biogas and sludge using fishery by-products are lacking. In addition, no studies on sludge reduction and biogas production using acidic fermentation of fishery by-products with rice bran have been published, to our knowledge. Rice bran contains around 38.3\% sugar,
This is an Open Access article distributed under the terms of the Creative Commons Attribution Non-Commercial License (http://creativecommons.org/licenses/by-nc/3.0/) which permits unrestricted non-commercial use, distribution, and reproduction in any medium, provided the original work is properly cited.

Copyright (C) 2021 Korean Society of Environmental Engineers
Received October 07, 2019 Accepted March 08, 2020

${ }^{\dagger}$ Corresponding author

Email: hjchoi@cku.ac.kr

Tel: +82 336497297 Fax: +82 336477635

ORCID: 0000-0003-3370-4277 
many inorganic nutrients, and minerals [14] that can shorten the acidogenic fermentation period of the FBs and may play an important role as an external carbon source, which is required for acidogenic fermentation. Therefore, this study focused on fermenting fishery by-products using rice bran and investigating the effects of sludge reduction and biogas production using this as an external carbon source.

Fishery by-products (FBs) are incidental wastes from production, distribution, processing, and sale of fish products such as fish bones, intestines, and blood [15]. Global seafood production in 2016 was around 171 million tonnes [16]. In 2017, Korea's fishery production was 2,273,000 tons, an increase of $14.5 \%$ over the previous year [17]. Depending on the type of fishery products, FBs comprise $20 \%$ to $80 \%$ of the mass, and more than 620,000 tons of FBs are generated annually in Korea [18]. FBs from large factories are mainly recycled into fish meal and feed [19]. However, most FBs treated in homes or small factories take the form of food waste [2, 15]. FBs contain large amounts (approximately 81-92\%) of various organic matter, including 62-79\% moisture, $7.0-12.5 \%$ nitrogen, 2.8-5.9\% $\mathrm{P}_{2} \mathrm{O}_{5}, 0.6-1.8 \% \mathrm{~K}_{2} \mathrm{O}, 1.8-5.1 \% \mathrm{CaO}, 0.1-0.4 \% \mathrm{MgO}$, and $0.3-0.8 \% \mathrm{Na}_{2} \mathrm{O}$ on a wet-weight basis, which provide very good conditions for microorganism growth [20]. Thus, FBs have great potential to convert to biogas through anaerobic digestion. Several previous studies have reported that combined digestion with fish waste and sewage sludge has significant potential for biomethane production, while studies on anaerobic digestion of fish wastes have shown biomethane production potentials ranging from 0.2 to $0.9\left(\mathrm{CH}_{4} \mathrm{~m}^{3} / \mathrm{kg}\right.$ VS $)[15,19,20]$.

Currently, anaerobic co-digestion with FBs uses a method of filtering, pulverizing, and adding solids directly into an anaerobic digester without acidogenic fermentation [13]. Previous studies have reported that FBs contain around $60 \%$ protein and $20 \%$ fat and minerals, depending on the species [16]. Therefore, when raw FBs are added directly to the anaerobic digester, they inhibit digestion efficiency due to (i) a rapid $\mathrm{pH}$ drop due to local acidogenic fermentation, (ii) scum conversion due to acidogenic fermentation rate differences, and (iii) the salts contained in FBs [19]. However, acidogenic fermentation of FBs produces acetic acid, butyric acid, etc., so the problems caused when FBs are directly injected can be reduced in advance [17]. In addition, in acidogenic fermentation of fishery by-product broth (FFB), there are many kinds of anaerobic bacteria in the acid production stage [17, 21]. Many of these various types of bacteria are less sensitive to various environmental changes than a single group of bacteria [19]. This study was conducted on acidogenic fermentation of FBs with rice bran (RFFB) and tap water (TFFB) to shorten the duration of acidogenic fermentation of FBs and to improve the digestion efficiency of anaerobic digesters. Finally, RFFB, TFFB, and non-acid fermented FBs were mixed with sewage sludge in an anaerobic tank, and the effects of this operation were compared to those of sewage reduction and biogas production in anaerobic co-digestion.

\section{Material and Methods}

\subsection{Acidogenic Fermentation of Fishery By-products}

Rice bran extract (RBE) was collected from farmers in Gangneung,
Korea. Collected rice bran was sieved through an 80 mesh (0.18 $\mathrm{mm}$ ) sieve to remove rice husk and contaminants. The sifted rice bran was dried for $24 \mathrm{~h}$ in an oven at $80^{\circ} \mathrm{C}$ to remove contaminating microorganisms. FBs were collected at the seafood processing plant in S-City, Korea. Materials not suitable for fermentation, such as plastic, vinyl, gravel, sand, and yarn, were removed and ground using a grinding machine (Waring Laboratory, USA). Then, 10\% $(\mathrm{v} / \mathrm{v})$ tap water or rice bran was added to the ground FBs, and the mixture was put in a $10 \mathrm{~L}$ circular reactor. It is difficult to transport the material if the TS content in the reactor is too high, which can cause the microorganism to decompose the substrate only in the close proximity. Therefore, $10 \%$ water was added to promote fermentation efficiency. The mixture was fermented in anaerobic acidogenic fermentation at $150 \mathrm{rpm}$ at $55^{\circ} \mathrm{C}$ without $\mathrm{pH}$ control. The fishery by-products fermented with tap water (TFFB) or fermented with rice bran (RFFB) were filtered through a $5 \mathrm{~mm}$ sieve to remove solids and were stored at room temperature before use in experiments.

\subsection{Sewage Sludge}

To test the effects of FFB on sludge reduction and biogas production, sewage sludge and different FFBs were mixed, and anaerobic co-digestion was performed. The inoculum sludge was collected from the bottom settlement of anaerobic fermentation tank that was fed with municipal waste in Sok-cho wastewater treatment plant operated by Gangwon-do, Korea, with a capacity of 46,000 ( $\left.\mathrm{m}^{3} / \mathrm{d}\right)$. The sewage treatment method uses intermittent aeration contact oxidation (DeNiPho). Sewage waste is separated from fresh sludge and surplus sludge for advanced treatment and biogas production; it is then concentrated and dehydrated. The average inflow at the municipal sewage treatment plant was $128.2-249.8\left(\mathrm{~m}^{3} / \mathrm{d}\right)$, and total solid (TS), volatile solid (VS), and VS/TS ratio were 4,800-18,023 $\mathrm{mg} / \mathrm{L}, 6,415-12,657 \mathrm{mg} / \mathrm{L}$, and 43.4-64.7\%, respectively.

\subsection{Experimental Design}

The experiment was conducted in batch-test mode using cylindrical reactor. The detailed experimental design and specific mixing ratio of sewage sludge and FFB are summarized in Table 1. The prepared TFFB and RFFB were each mixed with sewage sludge and introduced into a $10-\mathrm{L}$ reactor at a predetermined ratio. Sludge reduction and biogas production were then measured.

Among the various samples, SF1 consisted only of sewage sludge, serving as a control. SF2, SF3, and SF4 samples of sewage sludge were mixed TFFB, RFFB, and raw FBs with $50 \%$ based on volume of TS, respectively, to determine the influence of FFB on sludge reduction and biogas production. According to previous studies, sewage sludge reduction and biogas production are possible for sewage sludge at FFB ratios from 3: 7 to 5: 5 [19, 22, 23]. However, biogas production and sewage sludge reduction were optimal around ratios of 5:5. Therefore, the ratio of sewage sludge to FBs was set to 5:5 to increase sewage sludge reduction and improve FB treatment. The incubation time was $30 \mathrm{~d}$, and the temperature was $35^{\circ} \mathrm{C}$ to improve the growth of anaerobic microorganisms. According to the literature, methane-producing bacteria are very sensitive to the environment and are found in a wide range of temperatures between $0-97^{\circ} \mathrm{C}$, and they are divided into medium-temperature 
Table 1. Experimental Deign for Batch Testing

\begin{tabular}{|c|c|c|c|c|}
\hline Samples & SF1 & SF2 & SF3 & SF4 \\
\hline Injection condition & Sludge $100 \%$ & Sludge $50 \%+$ TFFB $50 \%$ & Sludge $50 \%+$ RFFB $50 \%$ & Sludge $50 \%+\mathrm{FBs} 50 \%$ \\
\hline Organic loading amount $(\mathrm{g} \mathrm{VS}$ in $/ \mathrm{L} \cdot \mathrm{d})$ & 2.06 & 3.36 & 4.12 & 2.96 \\
\hline Incubation time & & & $30 \mathrm{~d}$ & \\
\hline Temperature & & & $35^{\circ} \mathrm{C} \pm 1$ & \\
\hline Stirring speed & & & $150 \mathrm{rpm}$ & \\
\hline
\end{tabular}

digestion $\left(30-40^{\circ} \mathrm{C}\right)$ and high-temperature digestion $\left(45-60^{\circ} \mathrm{C}\right)$ depending on temperature [22]. The operation cost of anaerobic digesters at moderate temperature of $35^{\circ} \mathrm{C}$ is lower than that of high-temperature digestion $\left(>50^{\circ} \mathrm{C}\right)$ due to the lower energy requirements.

\subsection{Analytical Methods}

TS, VS, and TCOD were measured by sampling at a fixed time every day based on standard water pollution test methods [24]. All tests were performed three times, and the results were expressed as mean \pm standard deviation. Variance analysis (ANOVA) was used to test the significance of the results, and $\mathrm{p}<0.05$ was considered statistically significant. $\mathrm{pH}$ was measured using a $\mathrm{pH}$ meter (HM-30R, DDK-TOA), and volatile fatty acids (VFAs) were centrifuged for 15 minutes at $2000 \mathrm{rpm}$ for a $1 \mathrm{~mL}$ sample, and the supernatant was collected and analyzed using a liquid chromatography system (1260 LC system, Aligent, USA). An HPX-87H (300X $7.8 \mathrm{~mm}$, Biorad, USA) analysis column was used, and $5 \mathrm{mM}$ sulfuric acid $\left(\mathrm{H}_{2} \mathrm{SO}_{4}\right)$ was used as the mobile phase. The column temperature was $60^{\circ} \mathrm{C}$, and the flow rate was $0.6 \mathrm{~mL} / \mathrm{min}$. Biogas measurements were quantified daily by inserting a syringe through a rubber stopper on top of the serum bottle. The components of biogas $\left(\mathrm{CH}_{4}, \mathrm{CO}_{2}\right.$, $\mathrm{H}_{2} \mathrm{~S}, \mathrm{H}_{2}, \mathrm{NH}_{3}$, etc.) were analyzed by gas chromatography (GC) according to ASTM D7833-14 [25]. Assuming that each organic material was completely decomposed into methane and carbon dioxide in the anaerobic consolidation process, the theoretical methane yield $\left(\mathrm{Y}_{\mathrm{m}}\right)$ was calculated using the following stoichiometry based on the elemental composition of the organic material.

$$
\begin{gathered}
\mathrm{C}_{\mathrm{a}} \mathrm{H}_{\mathrm{b}} \mathrm{O}_{\mathrm{c}} \mathrm{N}_{\mathrm{d}}+\frac{(4 \mathrm{a}-\mathrm{b}-2 \mathrm{c}+3 \mathrm{~d})}{4} \mathrm{H}_{2} \mathrm{O} \rightarrow \\
\frac{(4 \mathrm{a}+\mathrm{b}-2 \mathrm{c}-3 \mathrm{~d})}{8} \mathrm{CH}_{4}+\frac{(4 \mathrm{a}-\mathrm{b}+2 \mathrm{c}+3 \mathrm{~d})}{8} \mathrm{CO}_{2}+\mathrm{d} \mathrm{NH}_{3} \\
\mathrm{Y}_{\mathrm{m}}=\frac{1000 \times 22.4 \times\left(\frac{4 \mathrm{a}+\mathrm{b}-2 \mathrm{c}-3 \mathrm{~d}}{8}\right)}{12 \mathrm{a}+\mathrm{b}+16 \mathrm{c}+14 \mathrm{~d}} \frac{\mathrm{mLCH}_{4}}{\mathrm{gVS}}
\end{gathered}
$$

The modified Gompertz equation was used for kinetic analysis of microorganisms for biogas production in the anaerobic co-digestion process:

$$
M=M_{\max } \exp \left[-\exp \frac{R_{m} e}{M_{\max }}(\lambda-t)+1\right]
$$

Here, $M$ is cumulative biogas production (mL/g.VS.d), $\mathrm{M}_{\max }$ is biogas yield potential $(\mathrm{mL} / \mathrm{g} \cdot \mathrm{VS} \cdot \mathrm{d}), \mathrm{R}_{\mathrm{m}}$ is maximum biogas production rate $(\mathrm{mL} / \mathrm{g} \cdot \mathrm{VS} \cdot \mathrm{d}), \lambda$ is duration of the lag phase $(\mathrm{d}), \mathrm{t}$ is cumulative methane production time, and e is Euler's constant.

\section{Results and Discussion}

\subsection{Acidogenic Fermentation of FBs with Rice Bran and Tap Water}

There are various reasons for using rice bran as an external carbo source in fish by-product fermentation. First, rice bran contains a large amount of sugar, which promotes fermentation of fishery-by products, shortens the fermentation period, and increases the content of acetic acid [14]. In addition, rice bran has the advantage of reduced cost relative to other external carbon sources and recycled resources because it is waste of milling rice [26]. According to previous studies, about $70 \%$ of the methane produced in anaerobic digestion comes from acetic acid and can have a significant effect on biogas production and sludge reduction in the anaerobic co-digestion process $[3,12,15,18,21]$. The experiments showed that the $\mathrm{pH}$ was 3.2 at $5 \mathrm{~d}$ of acidogenic fermentation when using rice bran (Fig. 1(a)). After $5 \mathrm{~d}$ of reaction, there was almost no change in $\mathrm{pH}$, indicating that acidogenic fermentation of the FBs had
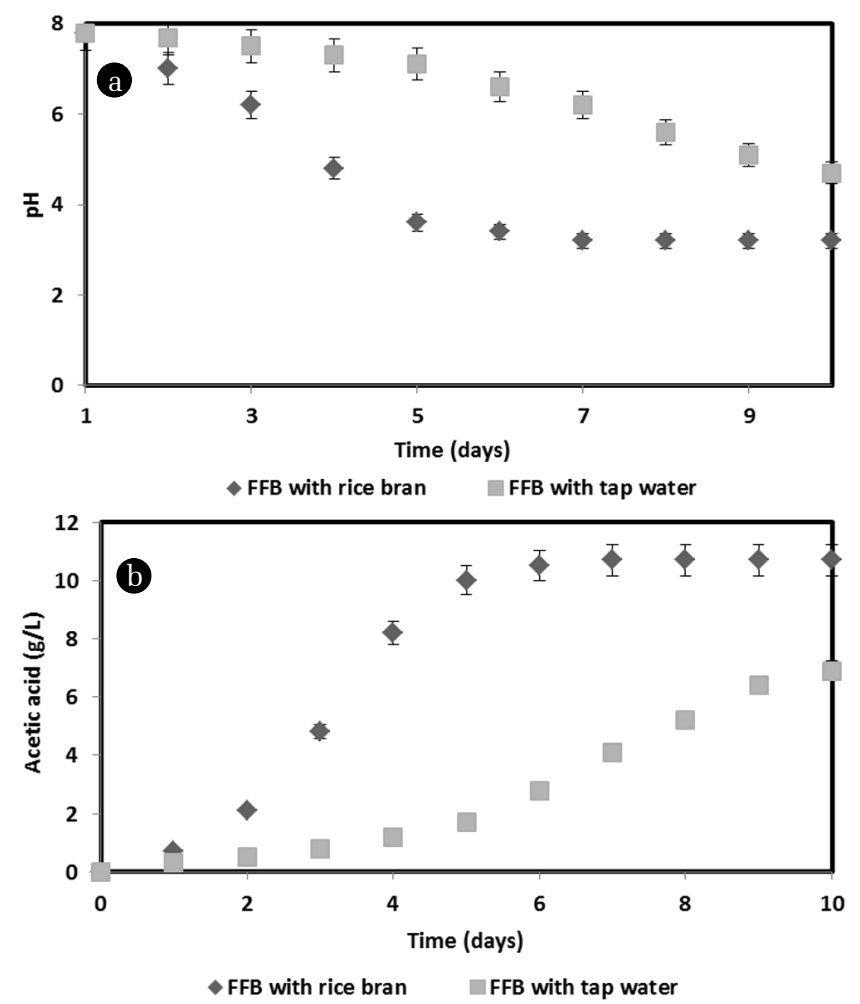

Fig. 1. Changes of $\mathrm{pH}$ (a) and acetic acid concentration (b) by FFB with rice bran and tap water. 
Table 2. Characteristics of the Samples with Different Materials

\begin{tabular}{|c|c|c|c|c|c|}
\hline & & SF1 & SF2 & SF3 & SF4 \\
\hline \multicolumn{2}{|l|}{$\mathrm{pH}$} & $7.5 \pm 0.4$ & $7.1 \pm 0.3$ & $6.8 \pm 0.2$ & $7.2 \pm 0.2$ \\
\hline \multicolumn{2}{|l|}{ TCOD (g/L) } & $27.5 \pm 2.7$ & $60.2 \pm 5.2$ & $72.8 \pm 5.6$ & $47.6 \pm 4.6$ \\
\hline \multicolumn{2}{|l|}{ Total Solids (TS) (g/L) } & $18.3 \pm 0.1$ & $23.2 \pm 2.1$ & $26.3 \pm 1.8$ & $21.7 \pm 2.3$ \\
\hline \multicolumn{2}{|c|}{ Volatile Solids (VS) (g/L) } & $10.3 \pm 0.4$ & $16.8 \pm 1.9$ & $20.6 \pm 2.2$ & $14.8 \pm 1.2$ \\
\hline \multicolumn{2}{|l|}{ VS/TS } & $0.56 \pm 0.02$ & $0.72 \pm 0.02$ & $0.78 \pm 0.02$ & $0.68 \pm 0.02$ \\
\hline \multicolumn{2}{|c|}{ Total Nitrogen (TN) (mg/L) } & $1315.2 \pm 8.6$ & $2632.4 \pm 1.4$ & $3092.8 \pm 2.3$ & $2017.8 \pm 10.2$ \\
\hline \multicolumn{2}{|c|}{ Total Phosphorus (TP) (mg/L) } & $15.3 \pm 1.6$ & $187.8 \pm 5.4$ & $276.5 \pm 4.2$ & $123.9 \pm 6.7$ \\
\hline \multicolumn{2}{|c|}{ Alkalinity (mg as $\mathrm{CaCO} / \mathrm{L}$ ) } & $2476.8 \pm 84.2$ & $1165.8 \pm 37.4$ & $654.2 \pm 28.4$ & $1764.5 \pm 45.2$ \\
\hline \multicolumn{2}{|l|}{$\mathrm{C}$ (\%, dry weight) } & $26.8 \pm 0.5$ & $36.6 \pm 0.9$ & $45.2 \pm 1.5$ & $32.2 \pm 1.2$ \\
\hline \multicolumn{2}{|l|}{$\mathrm{N}$ (\%, dry weight) } & $4.2 \pm 0.1$ & $4.0 \pm 0.3$ & $4.0 \pm 0.2$ & $4.1 \pm 0.4$ \\
\hline \multicolumn{2}{|l|}{$\mathrm{C} / \mathrm{N}$ ratio } & $6.44 \pm 0.1$ & $9.15 \pm 0.3$ & $11.30 \pm 0.4$ & $7.85 \pm 0.2$ \\
\hline \multirow{7}{*}{$\begin{array}{l}\text { Volatile Fatty Acids } \\
\text { (VFA) }(\mathrm{g} / \mathrm{L})\end{array}$} & Acetic acid & $0.5 \pm 0.1$ & $4.3 \pm 0.2$ & $7.8 \pm 0.2$ & $0.8 \pm 0.1$ \\
\hline & Propionic acid & $1.1 \pm 0.1$ & $1.1 \pm 0.0$ & $1.1 \pm 0.1$ & $1.1 \pm 0.1$ \\
\hline & Iso-butyric acid & $0.2 \pm 0.0$ & $0.3 \pm 0.0$ & $0.3 \pm 0.0$ & $0.2 \pm 0.0$ \\
\hline & Butyric acid & $0.5 \pm 0.0$ & $0.6 \pm 0.1$ & $0.6 \pm 0.1$ & $0.5 \pm 0.0$ \\
\hline & Iso-valeric acid & $0.2 \pm 0.0$ & $0.2 \pm 0.0$ & $0.2 \pm 0.0$ & $0.2 \pm 0.0$ \\
\hline & Valeric acid & $0.2 \pm 0.0$ & $0.2 \pm 0.0$ & $0.3 \pm 0.0$ & $0.2 \pm 0.0$ \\
\hline & VFAs & $2.7 \pm 0.3$ & $6.7 \pm 0.5$ & $10.3 \pm 0.4$ & $3.0 \pm 0.4$ \\
\hline
\end{tabular}

stabilized. The change in acetic acid concentration was similar to the change of $\mathrm{pH}$ and was not significant after $5 \mathrm{~d}$ of fermentation (Fig. 1(b)). On the other hand, when acidogenic fermentation was conducted using tap water, the initial reaction was very slow, and the $\mathrm{pH}$ gradually decreased. After $10 \mathrm{~d}$, the $\mathrm{pH}$ was 4.7 , and this change was much slower than the acidogenic fermentation using rice bran. The concentration of acetic acid also increased very slowly and was $6.9(\mathrm{~g} / \mathrm{L})$ after $10 \mathrm{~d}$ of acidogenic fermentation, resulting in slower reactions and lower acetic acid production. This may be because the sugar contained in rice bran promoted acidogenic fermentation of FBs. FBs contains a lot of salt and fat, so the acidogenic fermentation process is slow. Therefore, an external carbon source is required to promote the process, and rice bran is a suitable external carbon source for acidogenic fermentation of FBs.

\subsection{Characteristics of Samples}

Table 2 summarizes the characteristics of samples mixed with various materials based on the experimental design. The highest acetic acid content and lowest $\mathrm{pH}$ were observed for SF3 samples. Anaerobic co-digestion is influenced by various parameters such as $\mathrm{pH}$, residence time, substrate liquefaction, microbial mass, mixing ratio, and temperature. Many researchers have suggested a range of $\mathrm{pH}$ 6.0-8.0 as suitable for biogas production [3, 12, 20, 27]. The $\mathrm{pH}$ values of the samples in this experiment were 7.5 , 7.1, 6.2, and 7.2 for SF1, SF2, SF3, and SF4, respectively. All samples were in the range suitable for biogas production. The amount of volatile fatty acids (VFAs) in the anaerobic reactor affects $\mathrm{pH}$ and biogas production. The VFA concentration of each sample ranged from 2.7 to 10.3 (g/L). Lower $\mathrm{pH}$ values indicate higher concentrations of VFAs. As a result, the SF3 sample with the lowest $\mathrm{pH}$ resulted in higher VFAs compared to the other samples. Previous studies have reported that, in general, excessive accumulation of VFAs in an anaerobic digester will result in a lower $\mathrm{pH}$, which affects the balance of acid and methane-producing bacteria [23]. In other words, the low $\mathrm{pH}$ with accumulation of VFAs inhibits the activity of methane-producing bacteria, and the biogas production of the digester is suppressed [5, 28].

In addition, the initial $\mathrm{C} / \mathrm{N}$ ratio affects biogas production; the ratio was $6.4,9.15,11.30$, and 7.85 for SF1, SF2, SF3, and SF4, respectively. SF3 fermented with rice bran had the highest $\mathrm{C} / \mathrm{N}$ ratio of all samples. Microorganisms require carbon and nitrogen in the right ratio for cell growth and metabolism [7, 8]. The ratio of $\mathrm{C} / \mathrm{N}$ in the anaerobic co-digestion process should be balanced for cultivation of microorganisms [13]. According to the literature, the recommended ratio of $\mathrm{C} / \mathrm{N}$ for biological wastewater treatment ranges from 20:1 to 30:1 [13, 28]. However, in the anaerobic co-digestion process for production of biogas, the optimum $\mathrm{C} / \mathrm{N}$ ratio may vary depending on properties of the mixed materials, particle size, ammonia concentration, $\mathrm{pH}$, etc. For example, pig manure, peanut waste, and goat manure require low $\mathrm{C} / \mathrm{N}$ ratios of 7-15, 2-18, and 9-18, respectively [3, 12, 29]. However, rice straw, core waste, and sawdust require high $\mathrm{C} / \mathrm{N}$ ratios of 50-68, 139-151, and 199-501, respectively [9, 29, 30]. Excessively high $\mathrm{C} / \mathrm{N}$ ratio, i.e., very low nitrogen content of the anaerobic co-digestion process, affects microbial composition and metabolic pathways, inhibiting cell growth and biogas production [3, 7, 23]. In contrast, excessively low $\mathrm{C} / \mathrm{N}$ ratio inhibits methanogenesis due to release of a high concentration of free ammonia upon decomposition and accumulation of volatile fatty acids [12, 28]. Therefore, it is important to maintain an optimal $\mathrm{C} / \mathrm{N}$ ratio to increase biogas production and sludge reduction. The $\mathrm{C} / \mathrm{N}$ ratios of the samples in this experiment ranged from 6.4 to 11.30 and may affect production of biogas. The relatively low $\mathrm{C} / \mathrm{N}$ ratio of the samples is believed to affect biogas production. In addition, the initial acetic acid content of SF3 was highest, but the alkalinity concentration was lowest of the samples, and the ratio of VS/TS was $56-78 \%$ in all samples. 


\subsection{Sludge Reduction in Anaerobic Co-digestion}

The primary objectives of anaerobic co-digestion are biogas production and reduction of sewage sludge. Volatile solids reduction is a typical indicator of organic material reduction in anaerobic co-digestion [23, 28]. Generally, the reduction efficiency of activated sludge in an anaerobic digester is $30-45 \%$ [4]. However, sludge reduction efficiency has been increased by $60 \%$ due to development of sludge pretreatment technology and application of new technology [1, 3, 29]. Increasing sludge reduction leads to decomposition of organic matter and increased biogas generation. Volatile solids reduction efficiency is important because biogas production leads to an increase in methane gas generation, although there are some differences depending on the properties of the substrate [23, 31]. In this experiment, the COD reduction value was $30.4 \%, 68.5 \%$, 83.6\%, and $46.66 \%$ for SF1, SF2, SF3, and SF4, respectively (Fig. 2). These values were higher than those of TS and lower than those of VS reduction for all samples. Kainthola et al. [29] reported that reduction of COD is closely related to biogas production and is

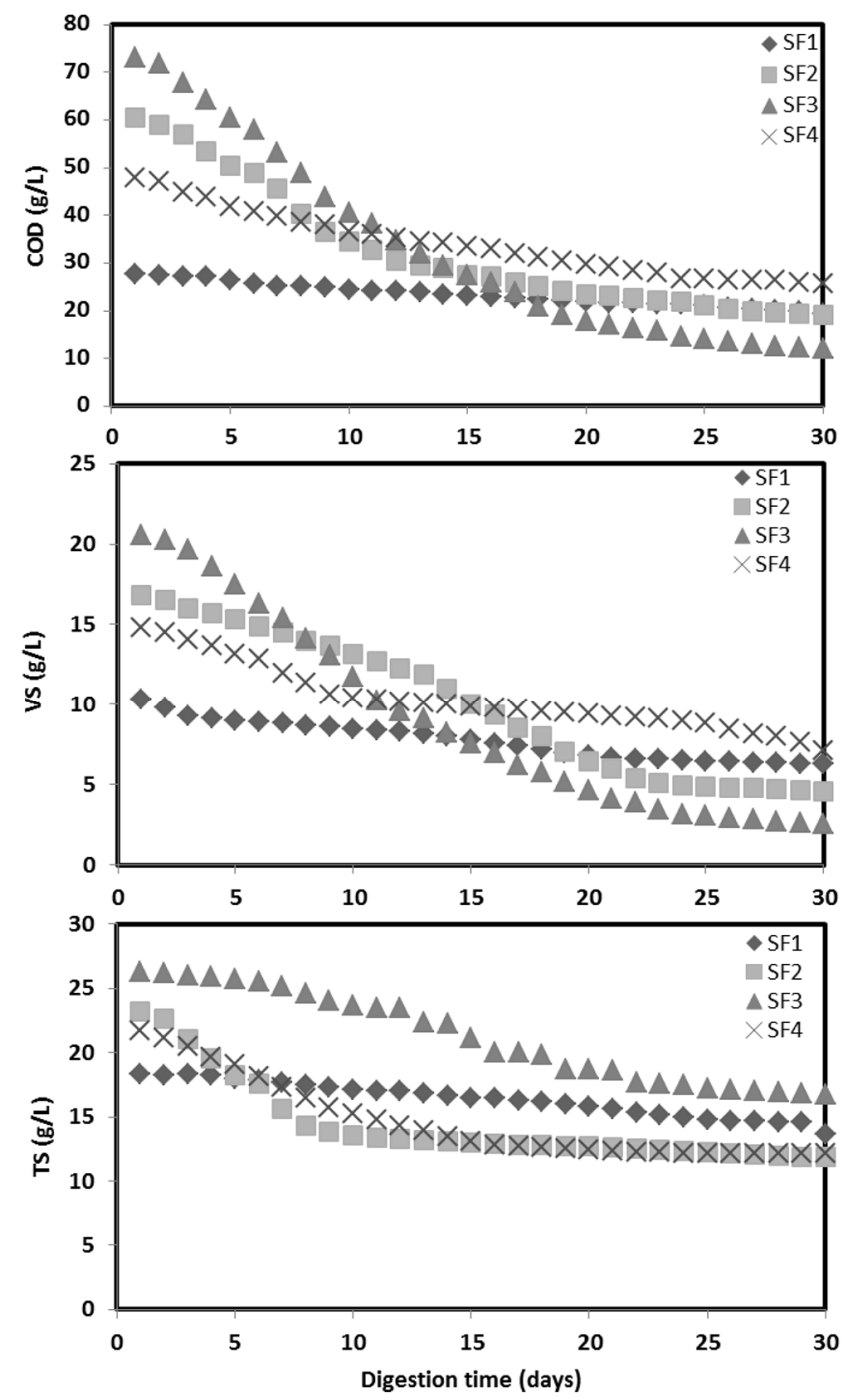

Fig. 2. Removal of COD, VS, and TS in anaerobic co-digestion. directly proportional to production of biogas. This reduction in COD in the anaerobic co-digestion process is thought to affect the production of biogas. The reaction of organic matter to methane gas is as follows:

$$
\text { Organic Matter } \rightarrow \mathrm{CH}_{4}+\mathrm{CO}_{2}+\mathrm{H}_{2}+\mathrm{H}_{2} \mathrm{~S}+\mathrm{NH}_{3}
$$

In general, when $1 \mathrm{~g}$ of COD is stabilized, $0.35 \mathrm{~L}$ of biogas is produced at $1 \mathrm{~atm}$ and $0{ }^{\circ} \mathrm{C}$, while $0.40 \mathrm{~L}$ of biogas is produced at $35^{\circ} \mathrm{C}$ [15]. In this experiment, the ratio of initial VS/TS of samples containing FBs was in the range of 0.68-0.78. In the anaerobic co-digestion process, VS removal efficiency was $39.2 \%$ for SF1, $72.5 \%$ for SF2, $87.6 \%$ for SF3, and $51.9 \%$ for SF4 (Fig. 2). The removal efficiency of SF3 was $48.4 \%$ higher than that of SF1 and $35.7 \%$ higher than that of SF4. The TS reduction for the anaerobic co-digestion process was $25.3 \%$ for SF1, $67.5 \%$ for SF2, $77.9 \%$ for SF3, and $43.5 \%$ for SF4. The TS reduction was lower than VS reduction in all samples. Khayum et al. [32] reported two-fold decrease in TS and VS, resulting in a 3-5-fold increase in biogas production. As the anaerobic bacteria became activated, the amount of sludge decreased, and biogas production increased. In this experiment, the removal efficiencies of COD, VS, and TS followed the order of SF3, SF2, SF4, and SF1.

\subsection{Kinetic Parameters}

Kinetics analysis of microorganisms for biogas production in the anaerobic co-digestion process uses a modified Gompertz equation (Eq. (2)), and the results are presented in Table 3. Analysis of kinetics in the anaerobic co-digestion process is used to determine the microbial degradation process, select the appropriate parameters to eliminate the mechanisms that interfere with the process, and to create a larger volume of biogas with an optimal experimental design [29]. Since production of biogas is closely related to growth of microorganisms, the biogas produced is a function of microbial growth [23].

The value of $\lambda$ (d), which is the lag phase constant, was lowest in SF3 at 1.09 and highest in SF1 at 8.86. The reaction delay time was shortest when using FFB, especially when fermented with rice bran. On the other hand, when biogas was produced by anaerobic fermentation using sewage sludge, a reaction delay time of 8.86 was required, compared to a reaction delay time of 5.12 (d) when biogas was produced using FBs. These results confirm that acidogenic fermentation improves the biodegradability of sewage sludge, which is the main reason for using FFB. $\mathrm{M}_{\max }$ is theoretical biogas yield, it can be calculated on the basis of elemental composition using

Table 3. Kinetic Parameters from Different Models in Anaerobic Co-digestion

\begin{tabular}{cccccc}
\hline Samples & $\boldsymbol{M}_{\text {max }}$ & $\boldsymbol{R}_{\boldsymbol{m}}$ & $\boldsymbol{\lambda}$ & $\boldsymbol{M}$ & $\mathbf{R}^{\mathbf{2}}$ \\
\hline SF1 & 446.23 & 19.31 & 8.86 & 411.93 & 0.9835 \\
SF2 & 1436.34 & 61.9 & 1.79 & 1305.12 & 0.9772 \\
SF3 & 1990.38 & 73.5 & 1.09 & 1593.58 & 0.9385 \\
SF4 & 1071.05 & 40.8 & 5.12 & 835.91 & 0.9174 \\
\hline
\end{tabular}

$M$ is cumulative biogas production (mL/gVS $\cdot \mathrm{d}$ ), $M_{\max }$ is biogas yield potential (mL/gVS·d), $R_{m}$ is maximum biogas production rate $(\mathrm{mL} / \mathrm{gVS} \cdot \mathrm{d})$ and $\lambda$ is duration of the lag phase (days) 
Eq.(1) and (2). There was a slight difference between the theoretical and actual production, and the amount of biogas produced was lower than the theoretically calculated amount in all samples. The values of $M$ and $R_{\max }$ appeared to be proportional to $\lambda$. In addition, the correlation coefficient $\left(\mathrm{R}^{2}\right)$ showed high significance as all samples were in the range of 0.92-0.98. Considering these results, the anaerobic co-digestion process of FFB with sewage sludge can be used to treat FBs and to increase productivity of biogas and reduce sewage sludge.

\subsection{Biogas Production in Anaerobic Co-digestion}

The organic loading amount (OLA) refers to the amount of organics that are continuously supplied to the anaerobic co-digestion process per day per unit of work. Most general sewage treatment plants operate around 1.2 to $10.5(\mathrm{kgVS} / \mathrm{L} \cdot \mathrm{d})$ or $2.2-35.7\left(\mathrm{kgCOD} / \mathrm{m}^{3} \cdot \mathrm{d}\right)$. The optimal OLA of an anaerobic consolidation process depends on various parameters, including nature of feed organics, operating temperature, and reaction time. Cumulative biogas production according to organic material loading amount (OLA) is depicted in Fig. 3, and initial organic load and biogas production are calculated and summarized in Table S1.

The VS loading amount increased from 2.06 to $4.12\left(\mathrm{gVS}_{\mathrm{in}} / \mathrm{L} \cdot \mathrm{d}\right)$. As the OLA was increased from 2.06 to $4.12\left(\mathrm{gVS}_{\mathrm{in}} / \mathrm{L} \cdot \mathrm{d}\right)$, the VS removal efficiency increased by $48.4 \%$, and the cumulative biogas increased from 411.93 to $1593.58\left(\mathrm{~mL} / \mathrm{m}^{3}\right)$. The COD loading amount was higher than the VS loading amount in all samples, ranging from 5.50 to $14.56\left(\mathrm{gCOD}_{\mathrm{in}} / \mathrm{L} \cdot \mathrm{d}\right)$. When the COD loading amount increased to $9.06\left(\mathrm{gCOD}_{\mathrm{in}} / \mathrm{L} \cdot \mathrm{d}\right)$, the COD removal efficiency and cumulative biogas increased by $53.19 \%$ and about $1181.65\left(\mathrm{~mL} / \mathrm{m}^{3}\right)$, respectively. Because OLA is a major factor affecting VS removal efficiency and biogas productivity, many researchers have studied various conditions to determine the optimal OLA [3, 7]. The optimum OLA of an anaerobic co-digestion system is determined by various parameters such as reaction conditions, type of organic matter, temperature, and incubation time [33]. Agyeman and Tao [7] suggested $3(\mathrm{gVS} / \mathrm{L} \cdot \mathrm{d})$ for anaerobic co-digestion of food waste and manure, Ganesh et al. [33] suggested $7.5(\mathrm{gVS} / \mathrm{L} \cdot \mathrm{d})$ for anaerobic co-digestion of activated sludge and food waste, and Aboudi et al. [34] published $11.2(\mathrm{gVS} / \mathrm{L} \cdot \mathrm{d})$ for anaerobic co-digestion of vegetable waste. In the present study, SF3 reached the highest cumulative biogas yield at $4.12\left(\mathrm{gVS}_{\mathrm{in}} / \mathrm{L} \cdot \mathrm{d}\right)$ and $14.56\left(\mathrm{gCOD}_{\mathrm{in}} / \mathrm{L} \cdot \mathrm{d}\right)$. In general, when the OLA is too low, nutritional deficiency occurs in the fermentation microorganisms, and the anaerobic co-digestion efficiency decreases, reducing the productivity of biogas. In contrast, an OLA that is too high results in accumulation of VFA in the anaerobic co-digester, which consequently inhibits activation of bacteria, reducing anaerobic co-digestion efficiency. However, several previous studies have indicated that biogas production generally increases in proportion to the increase in OLA [33]. In this study, the amount of cumulative biogas increased proportionally with the loading amount of VS and COD. These findings agree with those of previous studies [7].

The relation of cumulative biogas and removal of VS, TS and COD in anaerobic co-digestion by various samples was showed in Fig. S1. As the removal amount of VS, TS and COD in anaerobic co-digestion increased, cumulative biogas also increased. It can be seen that the removal amount of VS, TS and COD affected biogas production. In particular, SF3 has a faster onset of initial reaction and the highest sludge reduction and biogas production compared to other samples.

The results of methane gas production using various fish wastes in anaerobic co-digestion are summarized in Table 4. Samples mixed with sewage sludge and RFFB showed high methane production at the appropriate incubation time compared to samples using other materials. Comparative analysis showed that the amount of methane produced when FBs and rice bran were mixed was higher than that using only the FBs. The FBs/rice bran mixture produced about twice as much methane gas as that using tuna, sardine, and needlefish. Based on the above experimental results, use of RFFB for sludge reduction and biogas production in anaerobic co-digestion is very useful and efficient.
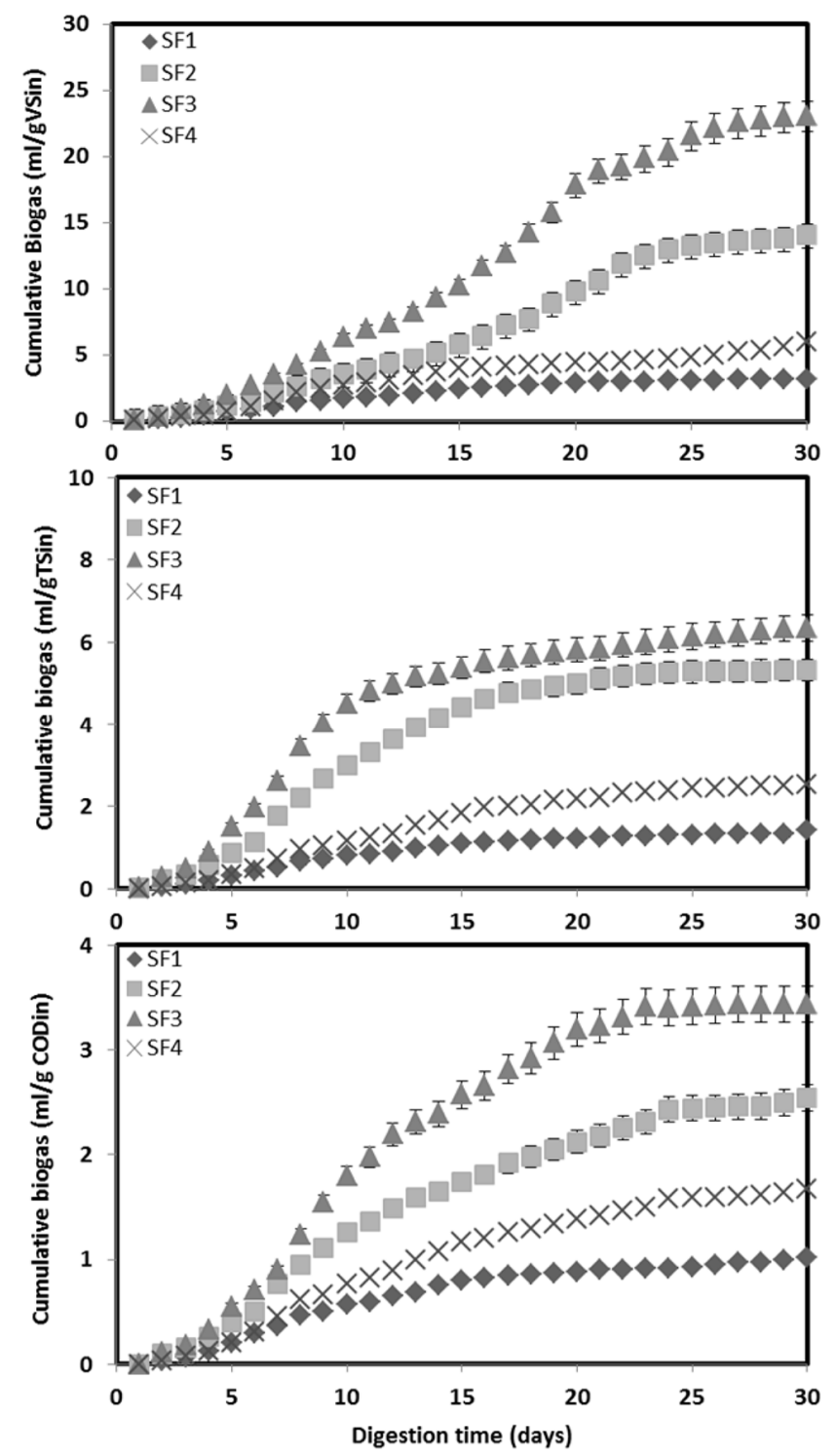

Fig. 3. Cumulative biogas production in anaerobic co-digestion. 
Table 4. Comparison of Methane Production for Anaerobic Co-digestion of Various Fish Wastes

\begin{tabular}{|c|c|c|c|}
\hline Type of waste (Substrate) & Incubation time (days) & Biomethane production & Reference \\
\hline Salmon heads & 33 & $0.83 \mathrm{CH}_{4} \mathrm{~m}^{3} / \mathrm{kg} \mathrm{VS}_{\text {added }}$ & {$[26]$} \\
\hline Nile perch waste & 42 & $0.50-0.61 \mathrm{CH}_{4} \mathrm{~m}^{3} / \mathrm{kg} \mathrm{VS}_{\text {added }}$ & [5] \\
\hline Round goby waste & - & $0.52-0.92 \mathrm{CH}_{4} \mathrm{~m}^{3} / \mathrm{kg} \mathrm{VS}_{\text {added }}$ & [19] \\
\hline Fish waste & 67 & $0.53-0.554 \mathrm{CH}_{4} \mathrm{~m}^{3} / \mathrm{kg} \mathrm{VS}_{\text {added }}$ & [21] \\
\hline Fish waste & 25 & $0.39 \mathrm{CH}_{4} \mathrm{~m}^{3} / \mathrm{kg} \mathrm{VS}$ added & {$[19]$} \\
\hline Fish waste & 28 & $0.46 \mathrm{~mL} \mathrm{CH} / \mathrm{kg} \mathrm{VS}$ & {$[15]$} \\
\hline Mackerel waste & 80 & $0.35 \mathrm{~L} \mathrm{CH}_{4} / \mathrm{g} \mathrm{VS}_{\text {added }}$ & [20] \\
\hline Tuna & 80 & $0.28 \mathrm{~L} \mathrm{CH}_{4} / \mathrm{g} \mathrm{VS}_{\text {added }}$ & {$[20]$} \\
\hline Sardine & 80 & $0.25 \mathrm{~L} \mathrm{CH}_{4} / \mathrm{g} \mathrm{VS}_{\text {added }}$ & {$[20]$} \\
\hline Needlefish & 80 & $0.26 \mathrm{~L} \mathrm{CH}_{4} / \mathrm{g} \mathrm{VS}_{\text {added }}$ & {$[20]$} \\
\hline Fish waste and bread waste silage $(20: 80(\%, \mathrm{TS}))$ & - & $0.48 \mathrm{CH}_{4} \mathrm{~m}^{3} / \mathrm{kg} \mathrm{VS}$ added & [6] \\
\hline Fish waste and cow manure $(16: 86)$ & - & $0.40 \mathrm{CH}_{4} \mathrm{~m}^{3} / \mathrm{kg} \mathrm{VS}$ added & [6] \\
\hline Sludge and TFFB (70:30 (\%, TS)) & 30 & $0.54 \mathrm{CH}_{4} \mathrm{~m}^{3} / \mathrm{kg}$ VS & This study \\
\hline Sludge and RFFB (70:30 (\%, TS)) & 30 & $0.57 \mathrm{CH}_{4} \mathrm{~m}^{3} / \mathrm{kg} \mathrm{VS}$ & This study \\
\hline Sludge and FBs (70:30 (\%, TS)) & 30 & $0.38 \mathrm{CH}_{4} \mathrm{~m}^{3} / \mathrm{kg} \mathrm{VS}$ & This study \\
\hline
\end{tabular}

\subsection{Characterization of Produced Biogas}

The biogases produced in this study using various materials are summarized in Table S2 by component. Analysis of the methane content of biogas showed value of $59.4 \%$ for SF1, 70.6\% for SF2, 71.9\% for SF3, and $66.8 \%$ for SF4. SF2 and SF3 yielded more than $70 \%$ methane. When FBs were fermented and used in anaerobic co-digestion, the content of methane in biogas was higher than that with raw FBs. The design criteria for biogas production facilities in terms of dry gas without moisture were 0.30-0.38 $\left(\mathrm{m}^{3} \mathrm{CH}_{4} / \mathrm{kgVS}_{\text {in }}\right.$ ) (food waste), 0.22-0.32 $\left(\mathrm{m}^{3} \mathrm{CH}_{4} / \mathrm{kgVS}_{\text {in }}\right.$ ) (livestock manure), and $0.10-0.28\left(\mathrm{~m}^{3} \mathrm{CH}_{4} / \mathrm{kgVS}_{\text {in }}\right.$ ) (sewage sludge) at standard conditions $\left(0^{\circ} \mathrm{C}, 1 \mathrm{~atm}\right)$ in Korea. The relationship between organic load and $\mathrm{CH}_{4}$ production using $\mathrm{FFB}$ and $\mathrm{FBs}$ in this experiment was $0.54,0.57$, and $0.38\left(\mathrm{~m}^{3} \mathrm{CH}_{4} / \mathrm{kgVS}_{\text {in }}\right)$ for SF2, SF3, and SF4, respectively. Methane production per VS was higher than that of FBs when using FFB but similar when TFFB and RFFB were used. However, use of either raw FBs or FFB as an organic carbon source for anaerobic co-digestion processes resulted in higher methane gas content than those with livestock manure, sewage sludge, and food waste.

The methane content of a typical anaerobic digestion gas ranges from $55 \%$ to $70 \%$ [15]. According to previous studies, higher methane content (over 70\%) results in higher quality biogas [22, 31]. Production of biogas using FFB is significant because it contains more methane than other feed stocks, offering the possibility of biogas production using FFB. In particular, SF2 and SF3 using TFFB and RFFB, respectively, had a lower $\mathrm{H}_{2} \mathrm{~S}$ content than SF1 without an FFB. Hydrogen sulfide is toxic and combines with the water vapor contained in biogas to form sulfuric acid, which should be removed when biogas is used as fuel because it is corrosive to metal $[20,21,29]$. Thus, low hydrogen sulfide content can reduce the post-treatment cost.

\subsection{Economic Evaluation}

The economic feasibility of using methane gas produced using
FFB and FBs was calculated and is represented in Table 5. The amount of recoverable energy was calculated by measuring the amount of methane in the biogas produced and using the calorific value of methane. The amount of methane produced per VS was highest in SF3 (5.71 kWh), followed by 5.41 for SF2 and 3.81 (kWh) for SF4. Based on biogas production results, organic matter reduction and methane content in biogas indicate that anaerobic co-digestion of sewage sludge and RFFB can treat the largest amount of FBs and recover the most energy.

Since FBs have the potential to be used as alternative energy sources as organic wastes, appropriate technologies have great significance in terms of reducing waste disposal costs and producing energy. In Korea, FBs are often treated by composting, feed, and incineration [2]. The cost of aerobic and anaerobic composting was on average 32.24 and 36.32 (US\$/ton), respectively [1, 2]. In addition, incineration, one of the treatment methods for FBs, costs 38.77 (US\$/ton), which is more expensive than composting [2]. Dry feed stuff was the most expensive treatment of FBs, 124.25 (US\$/ton), about three times as much as incineration and about 3.8 times as high as aerobic composting [3, 21, 31]. On the other hand, the combined process of FFB and sewage sludge was 17.38 (US\$/ton), which is the lowest treatment cost of all treatment methods. Anaerobic co-digestion of FBs and sewage sludge is more economical than other methods. In particular, compared with other treatment methods, waste can be disposed of at a low treatment cost, and energy can be recovered.

Table 5. $\mathrm{CH}_{4}$ and Energy Production According to Mixing Ratio

\begin{tabular}{lccc}
\hline Samples & $\begin{array}{c}\mathbf{C H}_{4} \text { production } \\
\text { ( }^{3} \mathbf{C H}_{4} / \mathbf{k g} \text { VS) }\end{array}$ & \multicolumn{2}{c}{ Energy production } \\
\cline { 3 - 4 } & 0.23 & 1982.6 & 2.31 \\
SF1 & 0.54 & 4654.8 & 5.41 \\
SF2 & 0.57 & 4913.4 & 5.71 \\
SF3 & 0.38 & 3275.6 & 3.81 \\
SF4 & &
\end{tabular}

a) $\mathrm{CH}_{4}$ production $\times 8,620 \mathrm{kcal} / \mathrm{m}^{3} \mathrm{CH}_{4}$, b)1 $\mathrm{kcal}=1.163 \mathrm{Wh}$ 


\section{Conclusions}

FBs were acidogenic fermentation using rice bran and tap water. RFFB, TFFB, and raw FBs were mixed with sewage sludge, and sewage sludge reduction and biogas production were compared in anaerobic co-digestion. The acidogenic fermentation process of FBs using rice bran was faster and produced more VFAs than that in tap water. Reductions in COD, VS, and TS were highest in SF3 samples. In kinetic analysis, $\lambda$ (d), which represents the response delay time, was 1.09 for SF3 and 8.86 for SF1. When FFB was used in anaerobic co-digestion, the reaction delay time of the anaerobic tank was short and was shortest when fermented with rice bran. VS loading amount increased from 2.06 to 4.12 (g VS/L·d), and VS reduction efficiency and cumulative biogas production increased $48.4 \%$ and from 411.93 to $1593.58\left(\mathrm{~mL} / \mathrm{m}^{3}\right)$ for various samples, respectively. COD loading amount were obtained in a range of 5.50 to $14.56\left(\mathrm{~g} \mathrm{COD}_{\mathrm{in}} / \mathrm{L} \cdot \mathrm{d}\right)$. As the loading amount of VS and COD increased, the amount of cumulative biogas also increased proportionally. The amount of methane produced per VS was highest in SF3. Energy recovery was highest in SF3 (5.71 kWh), followed by $5.41(\mathrm{kWh})$ in SF2 and $3.81(\mathrm{kWh})$ in $\mathrm{SF} 4$. Anaerobic co-digestion of FFB and sewage sludge is very useful for sludge reduction and bioenergy production when using discarded wastes as organic carbon sources. The processing cost of anaerobic co-digestion of FFB and sewage sludge is lower than that of composting or incineration. This strategy is economical in comparison with other methods because it can take advantage of the spare capacity of existing sewage treatment plants without investing in new facilities. Moreover, considering the income from energy recovery of methane gas, there is an advantage in that waste can be treated at a lower treatment cost than in the other treatment methods, and energy can be recovered.

\section{Acknowledgment}

This study was supported by the Basic Science Research Program through the National Research Foundation (NRF) of Korea, funded by the Ministry of Education, Science and Technology (2019R1H 1A280120).

\section{Author Contributions}

H-J Choi (Prof. Ph.D.) did conceptualization, methodology, data curation, writing- original draft preparation, visualization, investigation, software, validation, writing- reviewing and editing.

\section{References}

1. Kim YS, Yoon YM, Kim CH, Giersdorf J. Status biogas technologies and policies in South Korea. Renew. Sust. Energ. Rev. 2017;16:3430-3438

2. Ministry of Environment 2030. Sewage sludge reduction and biogas production utilization plan. Ministry of Environment in Korea 2012.

3. Siddique MNI, Wahid ZA. Achievements and perspectives of anaerobic co-digestion: A review. J. Clean. Prod. 2018;194: 359-371.

4. Nayak A, Bhushan B. An overview of the recent trends on the waste valorization techniques for food wastes. J. Environ. Manag. 2019;233:352-370.

5. Kassuwi SAA, Mshandete AM, Kivaisi AK. Anaerobic co0digestionof biological pre-treated Nile perch fish solid waste with vegetable fraction of market solid waste. ARPN J. Agri. Biol. Sci. 2012;7(12):1016-1031.

6. Solli L, Bergersen O, Sorheim R, Briseid T. Effects of gradually increased load of fish waste silage in co-digestion with cow manure on methane production. Waste Manag. 2014;34: 1553-1559.

7. Agyeman FO, Tao W. Anaerobic co-digestion of food waste and dairy manure: Effects of food waste particle size and organic loading rate. J. Environ. Manag. 2014;133:268-274.

8. Tang J, Wang XC, Hu Y, Pu Y, Li Y. Nutrients removal performance and sludge properties using anaerobic fermentation slurry from food waste as an external carbon source for wastewater treatment. Bioresour. Technol. 2019;271:125-135.

9. Herout M, Malatak J, Kucera L, Dlabaja T. Biogas composition depending on the type of plant biomass used. Res. Agric. Eng. 2011;57(4):137.

10. Rasi S, Veijanen A, Rintala J. Trace compounds of biogas from different biogas production plants. Energy 2007;32(8):1375-1380.

11. Lee DG, Yoon JJ. Biobutanol production from acid fermented solution of food waste using Clostridium sp. J. Korean Soc. Environ. Eng. 2018;40(5):211-216.

12. Ukpai PA, Nnabuchi MN. Comparative study of biogas production from cow dung, cow pea and cassava peeling using 45 liters biogas digester. Adv. Appl. Sci. Res. 2012;3(3):1864-1869.

13. Estevez MM, Sapci Z, Linjordet R, Morken J. Incorporation of fish by-product into the semi-continuous anaerobic co-digestion of pre-treated lignocellulose and cow manure, with recovery of digestate's nutrients. Renew. Energ. 2014;66:550-558.

14. Hou T, Chen N, Tong S, Li B, Feng C. Enhancement of rice bran as carbon and microbial sources on the nitrate removal from groundwater. Biochem. Eng. J. 2019;148:185-194.

15. Cadavid-Rodrígueza LS, Vargas-Muñoza MA, Plácido J. Biomethane from fish waste as a source of renewable energy for artisanal fishing communities. Sustain. Energ. Technol. 2019;34:110-115.

16. FAO. The State of World Fisheries and Aquaculture 2018 Meeting the sustainable development goals. Rome Licence: CC BY-NC-SA 3.0 IGO, 2018.

17. Shin WC, Yoon YK. Research on recycling of fish by-products. Issue report 2018, Chungnam Institute, Korea 2018.

18. Lee DJ, Bae J, Son J, Kang J, Jeon T, Shin S. A study on optimization of operation in the biogas production facility of organic water (III). National Inst. Environ. Res. Korea 2016.

19. Ivanovs K, Spalvins K, Blumberga D. Approach for modelling anaerobic digestion processes of fish waste. Energ. Procedia 2018;147:390-396.

20. Eiroa M, Costa JC, Alves MM, Kennes C, Veiga MC. Evaluation of the biomethane potential of solid fish waste. Waste Manag. 
2012;32:1347-1352.

21. Kafle GK, Kim SH. Evaluation of the biogas productivity potential of fish waste: A lab scale batch study. J. Biosyst. Eng. 2012;37(5):302-313.

22. Latha K, Velraj R, Shanmugam P, Sivanesan S. Mixing strategies of high solids anaerobic co-digestion using food waste with sewage sludge for enhanced biogas production. J. Clean. Prod. 2019;210:388-410.

23. Zhou M, Yan B, Wong JWC, Zhang Y. Enhanced volatile fatty acids production from anaerobic fermentation of food waste: A mini-review focusing on acidogenic metabolic pathways. Bioresour. Technol. 2018;248:68-78.

24. APHA. Standard methods for the examination of water and wastewater, 22nd edition edited by E. W. Rice, R. B. Baird, A. D. Eaton and L. S. Clesceri. American Public Health Association (APHA), American Water Works Association (AWWA) and Water Environment Federation (WEF), Washington, D.C. USA, 2012.

25. ASTM D7833 - 14. Standard Test Method for Determination of Hydrocarbons and Non-Hydrocarbon Gases in Gaseous Mixtures by Gas Chromatography, Active Standard ASTM D7833 | Developed by Subcommittee: D03.07, Book of Standards Volume: 05.06, 2018. https://www.astm.org.

26. Ertürk B, Meral R. The impact of stabilization on functional, molecular and thermal properties of rice bran. J. Cereal Sci. 2019;88:71-78.

27. Tabassum MR, Xia A, Murphy JD. The effect of seasonal variation on biomethane production from seaweed and on application as a gaseous transport biofuel. Bioresour. Technol. 2016;209:
213-219.

28. Esteban-Gutiérrez M, Garcia-Aguirre J, Irizar I, Aymerich E. From sewage sludge and agri-food waste to VFA: Individual acid production potential and up-scaling. Waste Manag. 2018;77:203-212.

29. Kainthola J, Kalamdhad AS, Goud VV. Enhanced methane production from anaerobic co-digestion of rice straw and hydrilla verticillata and its kinetic analysis. Biomass. Bioenerg. 2019;125:8-16.

30. Jena SP, Mishra S, Acharya SK, Mishra SK. An experimental approach to produce biogas from semi dried banana leaves. Sustain. Energ. Technol. 2017;19:173-178.

31. Corato U, Bari I, Viola E, Pugliese M. Assessing the main opportunities of integrated biorefining from agro-bioenergy co/by-products and agroindustrial residues into high-value added products associated to some emerging markets: A review. Renew. Sust. Energ. Rev. 2018;88:326-346.

32. Khayum N, Anbarasu S, Murugan S. Biogas potential from spent tea waste: A laboratory scale investigation of co-digestion with cow manure. Energy 2018;165:760-768.

33. Ganesh R, Torrijos M, Sousbie P, Steyer JP, Lugardon A, Delgenes JP. Anaerobic co-digestion of solid waste: effect of increasing organic loading rates and characterization of the solubilized organic matter. Bioresour. Technol. 2013;130:559-569.

34. Aboudi K, Álvarez-Gallego CJ, Romero-García LI. Semi-continuous anaerobic co-digestion of sugar beet byproduct and pig manure: effect of the organic loading rate (OLR) on process performance. Bioresour. Technol. 2015;194:283-290. 